\title{
Recycling of Solar Panel Waste Glass as a Partial Replacement of Meta- kaolinite in the Production of Geopolymers
}

\author{
HuiCong Hao ${ }^{1}$, Kae-Long Lin ${ }^{2}$,, DeYing Wang ${ }^{1}$, Sao-Jeng Chao ${ }^{3}$, Hau-Shing Shiu ${ }^{2}$, Ta-Wui Cheng ${ }^{4}$ \\ and Chao-Lung Hwang ${ }^{5}$
}

\author{
${ }^{1}$ Department of Environmental and Material Engineering, Yan-Tai University, China \\ ${ }^{2}$ Department of Environmental Engineering, National Ilan University, Taiwan \\ ${ }^{3}$ Department of Civil Engineering, National Ilan University, Taiwan. \\ ${ }^{4}$ Institute of Mineral Resources Engineering, National Taipei University of Technology, Taiwan \\ ${ }^{5}$ Department of Construction Engineering, National Taiwan University of Science and Technology, Taiwan
}

\begin{abstract}
This investigation elucidates the mechanical characteristics of geopolymer containing solar panel waste glass. With the $\mathrm{SiO} 2 / \mathrm{Na} 2 \mathrm{O}$ molar ratio $(\mathrm{S} / \mathrm{N}=0.75,1.0,1.25,1.5,1.75)$, the percentage of metakaolinite that is replaced by solar panel waste glass (0- 40\%), and the curing time of 1,7 , and 28 days as the study variables, the porosity, density, setting time, compressive strength, and flexural strength of the geopolymer were evaluated. The morphology of geopolymer was examined using Scanning Electron Microscopy (SEM), and its microstructural properties were examined through Fourier transform infrared spectroscopy (FTIR) analysis. The results demonstrate that the S/N molar ratio significantly influences the mechanical and morphological characteristics of geopolymers. The geopolymer containing solar panel waste glass with an $\mathrm{S} / \mathrm{N}$ of 1.75 had the greatest compressive strength. The intensity of the peak that represented Si-O-Al bonding of the geopolymer containing solar panel waste glass increased with the $\mathrm{S} / \mathrm{N}$. Analysis of the sample morphology revealed that the microstructures of stronger samples were more homogeneous and appeared denser. Furthermore, solar panel waste glass has the potential to partially replace metakaolinite as a geopolymer material, and to exhibit favorable mechanical characteristics.
\end{abstract}

Keywords: Compressive strength, flexural strength, geopolymer, microstructural, solar panel waste glass, setting time.

\section{INTRODUCTION}

Geopolymers are formed by activating aluminosilicates with alkaline or alkaline-silicate solutions at ambient temperature or higher. This approach was developed by Davidovits [1]. The main parameters of the geochemical reaction of geopolymer systems include the molar ratios of $\mathrm{SiO}_{2} / \mathrm{M}_{2} \mathrm{O}$ $\left(\mathrm{M}=\mathrm{Na}^{+}\right.$and $/$or $\left.\mathrm{K}^{+}\right)$and $\mathrm{Si} / \mathrm{Al}$ and the concentration of $\mathrm{MOH}$ [2]. The latter two parameters have been discussed extensively [3-6]. Although the effects of $\mathrm{S} / \mathrm{N}$ have been mentioned in some investigations [7-9], discussions have not been extended to systems that include solar panel waste glass. The present investigation focuses on the effect of $\mathrm{S} / \mathrm{N}$ on the properties of geopolymer products.

According to the IEO2007, the global emission of carbon dioxide, which was measured at $26.9 \times 1012 \mathrm{~kg}$ in 2004 , will increase to $33.9 \times 1012 \mathrm{~kg}$ in 2015 and $42.9 \times 1012 \mathrm{~kg}$ in 2030 , or by $59 \%$ over the projected period [10]. Carbon dioxide emissions contribute significantly to climate

*Address correspondence to this author at the Department of Environmental Engineering, National Ilan University, Taiwan; Tel: (886) 3-9357400; Ext: 7579; Fax: (886) 3-9364277; E-mail: kllin@niu.edu.tw deterioration, and therefore, more attention must be given to the life cycle of carbon emissions. Low-emission renewable energy sources, such as solar photovoltaic (PV) technology, are experiencing rapid growth [11]. The amount of glass recovered after recycling various types of $\mathrm{PV}$ modules is reported to be between 16 and $17 \mathrm{~kg} \mathrm{~m}^{-2}$. With the rapid expansion of the PV industry, the challenge of waste disposal in 25-30 years is anticipated to be serious [12]. Additionally, according to Taiwan's Environmental Protection Administration (EPA), the total amount of waste glass that has been dumped into landfills is approximately 0.52 million tons, whereas the amount of solar panel waste glass has reached 1000 tons [13]. Waste materials are traditionally discarded in landfills and often dumped directly into ecosystems without adequate treatment. Therefore, reuse and recycling alternatives should be investigated and implemented. The recent environmental approach aims to achieve sustainable development through the conservation of natural resources and by minimizing the discarding of materials. Today, reusing and recycling waste materials after their potentialities have been detected is an activity that can contribute to product diversification, the reduction of production costs, the provision of alternative raw materials for various industrial sectors, nonrenewable resource conservation, energy saving, and especially improved public health [14]. In this work, a dense ma- 
trix, the mechanical properties of which are suitable for civil engineering projects, is obtained from geopolymers containing solar panel waste glass. The studied variables are the $\mathrm{S} / \mathrm{N}$ molar ratio $(\mathrm{S} / \mathrm{N}=0.75,1.0,1.25,1.5$, and 1.75$)$, the percentage of metakaolinite replaced by waste glass $(0 \%, 10 \%$, $20 \%, 30 \%$, and $40 \%$ ), and the curing time (1, 7, and 28 days). The microstructure of all the samples was determined using Fourier transformation infrared spectroscopy (FTIR) and scanning electron microscopy (SEM).

\section{EXPERIMENTAL}

\subsection{Materials}

The geopolymer was synthesized from metakaolinite, which was prepared by calcining kaolinite from Taiwan at $650{ }^{\circ} \mathrm{C}$ for $3 \mathrm{~h}$. Solar panel waste glass was collected from a solar panel manufacturing plant in Taiwan. Approximately $500 \mathrm{~kg}$ were collected to ensure that the metakaolinite and solar panel waste glass samples were representative. The metakaolinite and solar panel waste glass were then pulverized with a ball mill until they could pass through a 200 mesh sieve. The solar panel waste glass was ground to a fineness value (on Blaine) of approximately $360 \mathrm{~m}^{2} \mathrm{~kg}^{-1}$. The resultant pulverized solar panel waste glass was desiccated before testing. Sodium silicate solution contained $29.5 \mathrm{wt} \%$ $\mathrm{SiO}_{2}$ and $9.0 \mathrm{wt} \% \mathrm{Na}_{2} \mathrm{O}$ for the $\mathrm{SiO}_{2} / \mathrm{Na}_{2} \mathrm{O}$ mole ratio of 3.2, and $10 \mathrm{M}$ sodium hydroxide solution [15] was used as alkaline reagents.

\subsection{Preparation of Geopolymer Samples}

The effects of the solid-to-liquid ratio and the amount of added waste glass on the strength of the geopolymer pastes

Table 1. Ratio of Raw Materials in Mixture

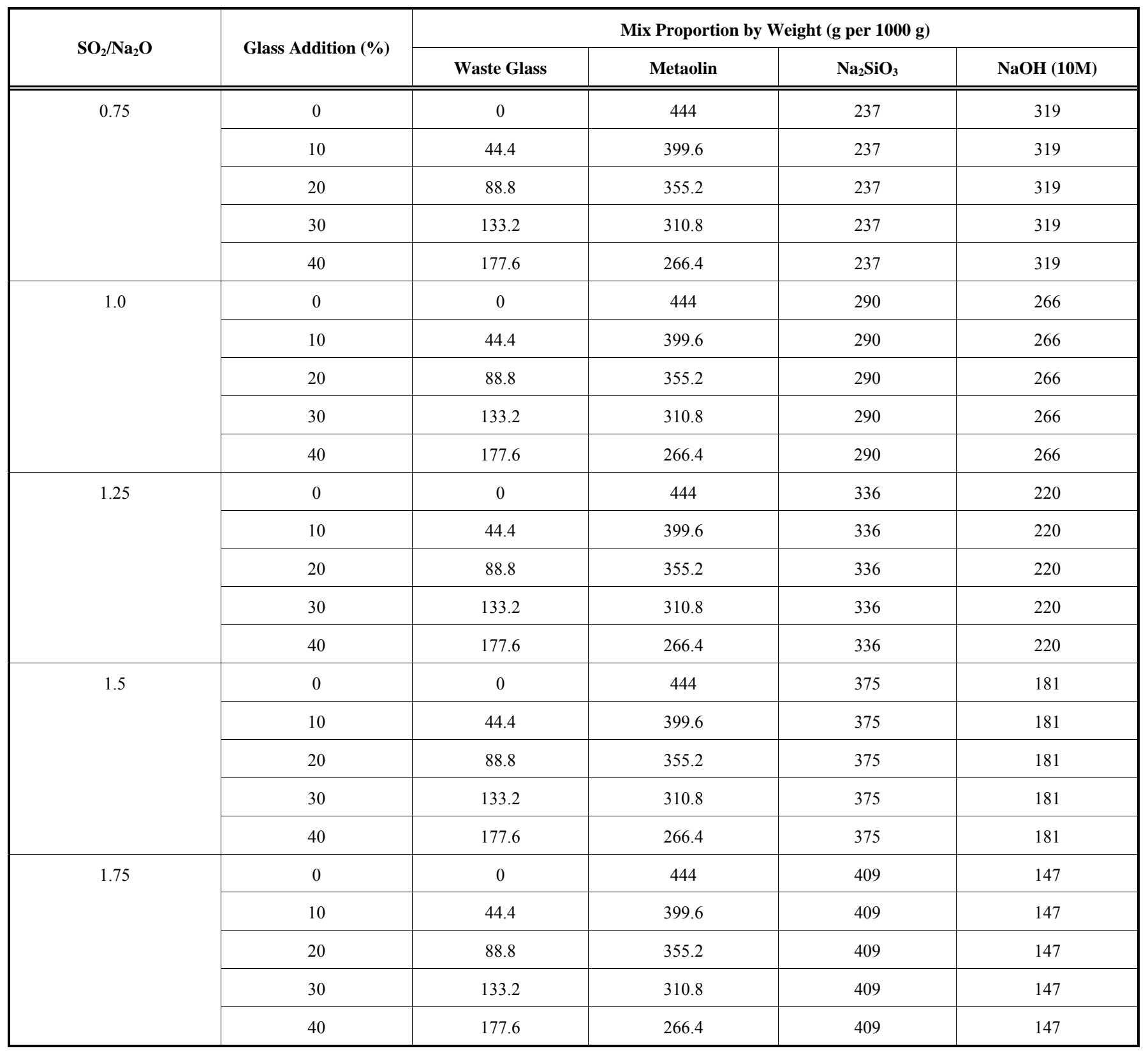


were examined. Table 1 presents the blend ratios of the geopolymer samples. Geopolymer pastes were prepared as follows: 1) Alkaline solution was made from a solution of sodium hydroxide and sodium silicate mixed in a planetary mixer for $6 \mathrm{~min}$; 2) the metakaolinite and solar panel waste glass powder were mixed with the alkaline solutions in a mechanical mixer for 6 min to produce a homogeneous paste; and 3) the homogenous slurry was poured into cubic plastic molds, which were then sealed. Samples were cured in a laboratory oven at $30^{\circ} \mathrm{C}$ for $24 \mathrm{~h}$ before they were removed from the molds.

\subsection{Analytical Methods}

The geopolymers containing $0 \%-40 \%$ solar panel waste glass underwent a series of tests to determine their quality. The porosity and bulk density were evaluated according to Archimedes' method [15]. Compressive strength tests were conducted after 1,7 , and 28 days on $50 \mathrm{~mm}$ cubic samples, according to ASTM C109 [16]. Flexural strength tests were performed after the same numbers of days of curing using 40 $\times 40 \times 160 \mathrm{~mm}$ samples, according to ASTM C348 [17].

$\mathrm{X}$-ray fluorescence (XRF) analysis was performed using an automated RIX 2000 spectrometer. Specimens were prepared for XRF analysis by mixing $0.4 \mathrm{~g}$ of sample and $4 \mathrm{~g}$ of 100 Spectroflux to yield a dilution ratio of 1:10 [18]. The homogenized mixtures were placed in Pt-Au crucibles before being heated for $1 \mathrm{~h}$ at $1000{ }^{\circ} \mathrm{C}$ in an electrical furnace. The homogeneous melted sample was recast into glass beads 2 $\mathrm{mm}$ in thickness and $32 \mathrm{~mm}$ in diameter.

The degree of reaction of the geopolymer was estimated using the expression suggested by Fernández-Jimenez et al. [19]. The geopolymer samples were attacked by $250 \mathrm{ml}$ of (1: 20) $\mathrm{HCl}$. The geopolymer samples were stirred for $3 \mathrm{~h}$ using a plastic rotor, and then filtered and washed in deionized water to a neutral $\mathrm{pH}$. The insoluble residue was first dried at $100{ }^{\circ} \mathrm{C}$, and the residue was regarded as the unreacted part of the raw material. Equation (1) yields the degree of reaction $\alpha$ :

$\alpha=\frac{m_{\text {initial }}-m_{\text {final }}}{m_{\text {initial }}} \times 100 \%$

where $m_{\text {initial }}$ is the initial weight of the sample, and $m_{\text {final }}$ represents the final weight of the insoluble residue following the $\mathrm{HCl}$ attack.
The chemical composition was determined by X-ray fluorescence (XRF), using an automated RIX 2000 spectrometer. Fourier transformation infrared spectroscopy (FTIR) was performed on the samples using a Bomem DA8.3 spectrometer and the $\mathrm{KBr}$ pellet technique $(1 \mathrm{mg}$ powdered sample mixed with $150 \mathrm{mg} \mathrm{KBr}$ ). A Hitachi S$3500 \mathrm{~N}$ scanning electron microscope was used to make SEM observations.

\section{RESULTS AND DISCUSSION}

\subsection{Characteristics of Materials}

The results demonstrate that the $\mathrm{pH}$ of the solar panel waste glass is 10.15 , and its density is $2.19 \mathrm{~g} \mathrm{~cm}^{-3}$. The $\mathrm{pH}$ of kaolinite and metakaolinite are 6.42 and 6.12 , respectively. The densities of kaolinite and metakaolinite are $2.13 \mathrm{~g} \mathrm{~cm}^{-3}$ and $2.24 \mathrm{~g} \mathrm{~cm}^{-3}$, respectively. Table 2 shows that the chemical composition of the solar panel waste glass and metakaolinite was rich in $\mathrm{SiO}_{2}$ and $\mathrm{Al}_{2} \mathrm{O}_{3}$, and the major components in solar panel waste glass were $\mathrm{SiO}_{2}(72.33 \%), \mathrm{Na}_{2} \mathrm{O}$ $(12.87 \%)$, and $\mathrm{CaO}(8.98 \%)$, indicating that the main constituents of metakaolinite were $\mathrm{SiO}_{2}(59.6 \%)$ and $\mathrm{Al}_{2} \mathrm{O}_{3}$ $(38.0 \%)$.

\subsection{Mechanical Characteristics of Geopolymer Contain- ing Solar Panel Waste Glass}

Fig. (1) presents the bulk density of geopolymer containing solar panel waste glass with various $\mathrm{S} / \mathrm{N}$ after 1,7 , and 28 days of curing. The bulk density of the geopolymer clearly increased as the $\mathrm{S} / \mathrm{N}$ increased, and decreased when the waste glass was added, probably because the structure of the geopolymer sample became denser as $\mathrm{S} / \mathrm{N}$ increased and as more viscous sodium silicate solution was added to the alkaline solution, and the sample became less compact as the amount of waste glass increased. According to the experimental results obtained by Delair et al. [20], during successive immersions, the $\mathrm{Na}^{+}$form gradually released species, which indicated that these species were more difficult to react and/or they were more difficult to be reached. Si was also measured in the solution and was probably due to the dissolution of the geopolymer containing solar panel waste glass or the presence of $\mathrm{Na}_{2} \mathrm{Si}_{2} \mathrm{O}_{5}$. This compound could be formed initially according to the $\mathrm{SiO}_{2}-\mathrm{Na}_{2} \mathrm{O}$ phase diagram. The compounds formed in $\mathrm{Na}$ : the geopolymer network and $\mathrm{M}_{2} \mathrm{Si}_{2} \mathrm{O}_{5}\left(\mathrm{M}=\mathrm{Na}^{+}\right.$or $\left.\mathrm{K}^{+}\right)$. However, as a function of the alkaline element, the $\mathrm{M}_{2} \mathrm{Si}_{2} \mathrm{O}_{5}$ compound exhibited a notable

Table 2. Chemical Composition of Raw Materials

\begin{tabular}{|c|c|c|c|}
\hline Composition (\%) & Kaolinite & Metakaolinite & Waste Glass \\
\hline \hline $\mathrm{SiO}_{2}$ & 53.70 & 59.60 & 72.33 \\
\hline $\mathrm{Al}_{2} \mathrm{O}_{3}$ & 37.88 & 38.00 & 1.90 \\
\hline $\mathrm{Fe}_{2} \mathrm{O}_{3}$ & 0.88 & 1.30 & 0.03 \\
\hline $\mathrm{Na}_{2} \mathrm{O}$ & $\mathrm{N} . \mathrm{D}$. & N.D. & 12.87 \\
\hline $\mathrm{CaO}$ & 0.20 & 0.25 & 8.98 \\
\hline $\mathrm{SO}_{3}$ & $\mathrm{ND}$ & 0.04 & 0.29 \\
\hline
\end{tabular}

ND: Not detected. 

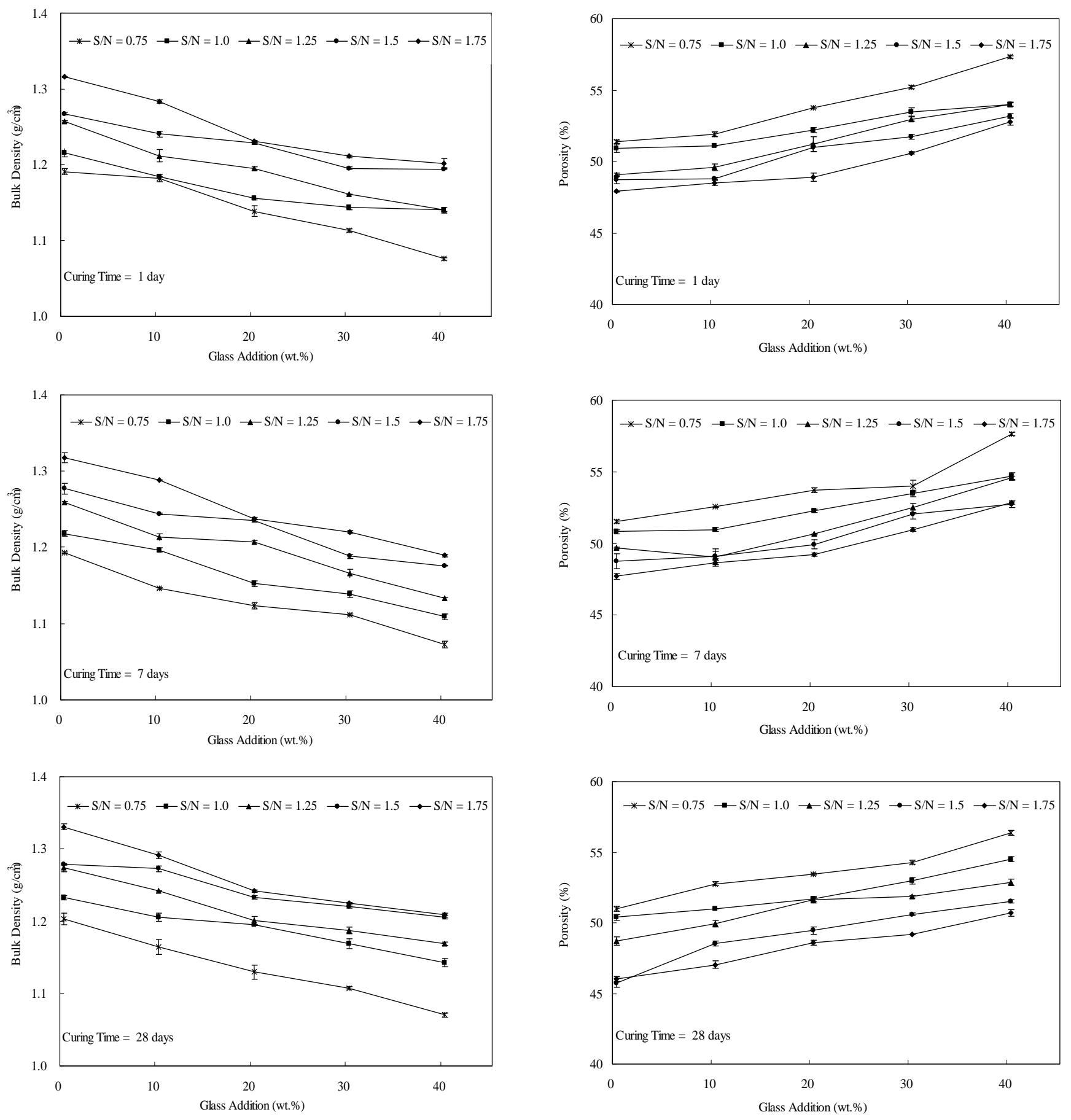

Fig. (1). Bulk density of geopolymer at various $\mathrm{S} / \mathrm{N}$.

difference in its hygroscopic property, which can be attributed to its differing resistance in acidic media [20-22]. Fig. (2) shows the porosity of the geopolymer with solar panel waste glass. The porosity of the geopolymer sample varied conversely with the density of the sample, increasing with $\mathrm{S} / \mathrm{N}$ and decreasing with the addition of solar panel waste glass. The results demonstrate that increasing the $\mathrm{S} / \mathrm{N}$ of the geopolymer densified its structure, and adding more waste glass to the system loosened its structure. When the porosity of geopolymer containing $10 \%$ solar panel waste glass similar to pure metakaolinite-based geopolymer in

Fig. (2). Porosity of geopolymer at various $\mathrm{S} / \mathrm{N}$.

$\mathrm{S} / \mathrm{N}=0.75$ and 1.0. Evidence exists for the release of alkaline elements from the geopolymer containing $10 \%$ solar panel waste glass and some silicon. This release could lead to changes in porosity. Moreover, a previous work based on inorganic polymer binders showed a strong correlation between their permeability and resistance to acid attacks [23, 24]. This last result is attributed to the reduction in mass transport rates through the finer pore network of such binders. Furthermore, the bulk density of the geopolymer increased with curing time, whereas its porosity decreased. 


\subsection{Setting Time of Geopolymer Contained Solar Panel Waste Glass}

In this investigation, the setting time of the geopolymer was measured using a Vicat needle and by recording the time required by a needle with a cross-sectional area of $1 \mathrm{~mm}$ to penetrate the softening sample after the geopolymer paste was poured into a mold. The initial time began when the needle had penetrated $25 \mathrm{~mm}$ of the sample, and the final time was reached when the needle could not visibly sink further into the paste.

Fig. (3) shows the initial setting time of geopolymer containing solar panel waste glass. The setting time is a function of $\mathrm{S} / \mathrm{N}$ and the amount of solar panel waste glass. The initial setting time increased as the $\mathrm{S} / \mathrm{N}$ molar ratio increased, possibly because the sodium silicate solution was more viscous than sodium hydroxide, and the larger silicate oligomers that were formed required more time to harden into the gel with the increasing $\mathrm{S} / \mathrm{N}$. Moreover, as more waste glass was added, the setting time increased, indicating that the glass diluted the system.
Fig. (4) shows the final setting time of the geopolymer, which varied according to the initial setting time. The initial and final setting times of the samples containing $10 \%$ waste glass at $\mathrm{S} / \mathrm{N}=0.75,1.0,1.25,1.5$, and 1.75 were $0.58,0.67$, $0.83,1.72,2.58 \mathrm{~h}$ and $0.83,1,1.17,2.05,3.08 \mathrm{~h}$, respectively. The final setting time of all the samples was less than $5 \mathrm{~h}$, revealing that each sample could be used in practical engineering applications.

\subsection{Compressive Strength of Geopolymer Contained So- lar Panel Waste Glass}

Fig. (5) presents the mean compression strengths of the samples with $\mathrm{S} / \mathrm{N}=0.75,1.0,1.25,1.5$, and 1.75 containing $0 \%-40 \%$ waste glass cured for various time. As expected, the compressive strength of the geopolymer increased as $\mathrm{S} / \mathrm{N}$ increased, and the sample with $\mathrm{S} / \mathrm{N}=1.75$ had the highest compressive strength, probably because an aluminosilicate polymeric reaction proceeded between $\mathrm{Al}(\mathrm{OH})^{4-}$ and mainly larger silicate oligomers, and an increased $\mathrm{S} / \mathrm{N}$ ratio promoted the formation of larger silicate oligomers.

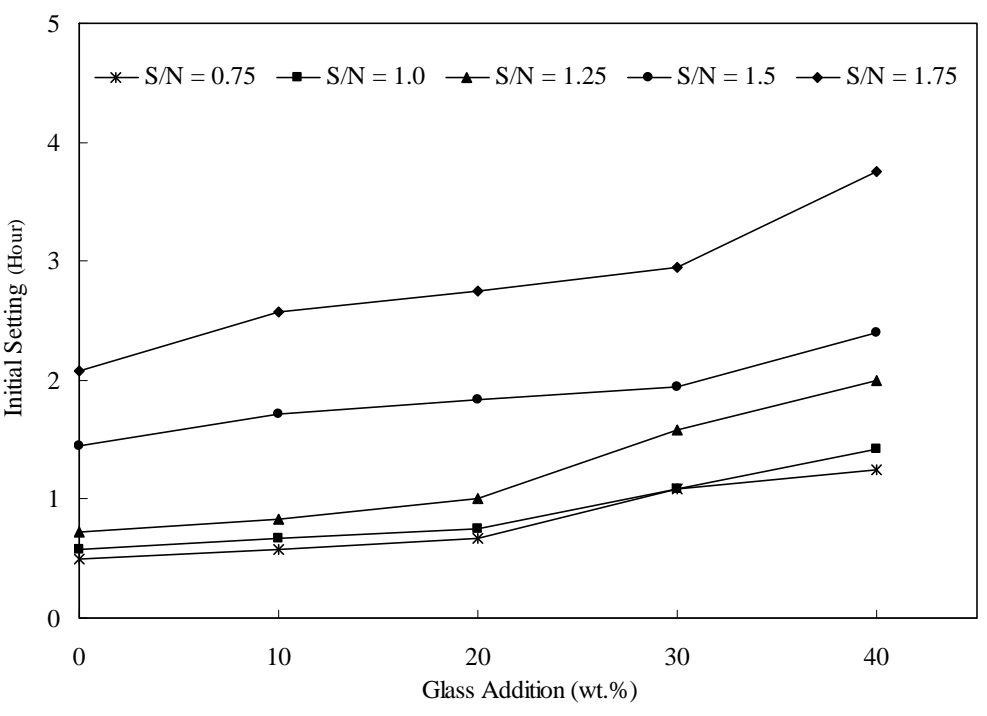

Fig. (3). Initial setting time of geopolymer at various $\mathrm{S} / \mathrm{N}$.

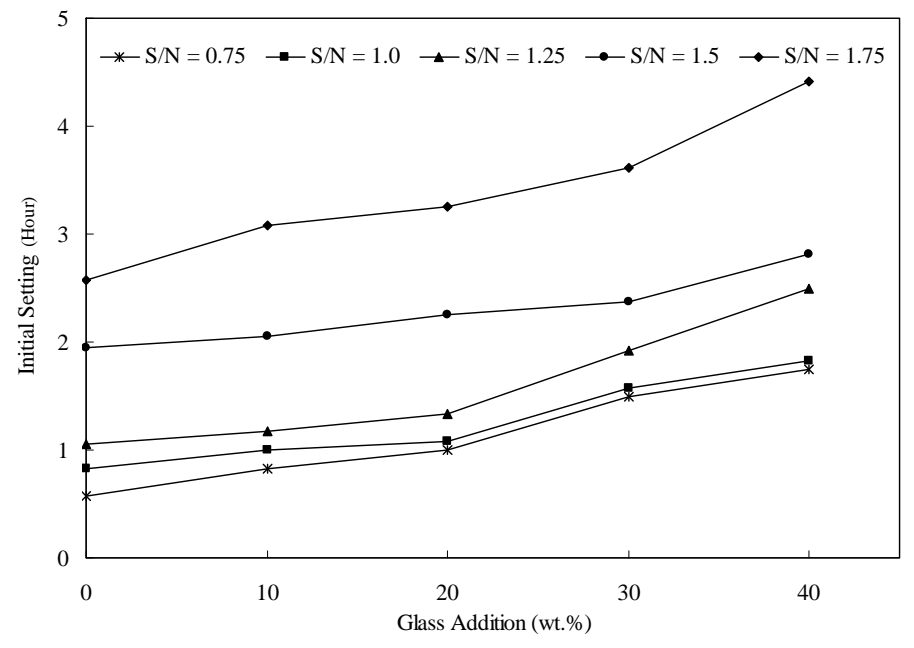

Fig. (4). Final setting time of geopolymer at various $\mathrm{S} / \mathrm{N}$. 

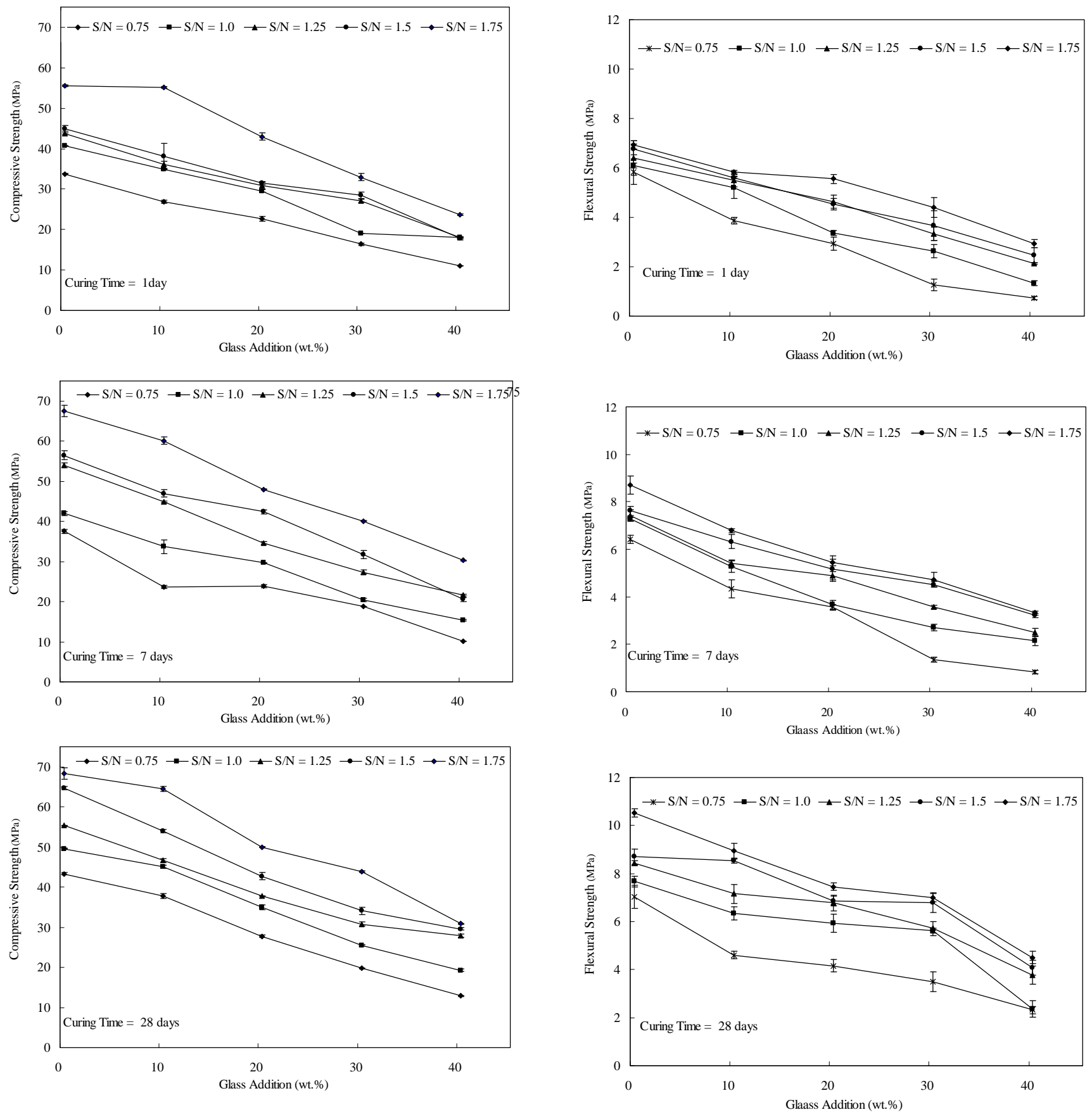

Fig. (5). Compressive strength of geopolymer at various $\mathrm{S} / \mathrm{N}$.

The compressive strength of geopolymer-containing solar panel waste glass decreased as the amount of solar panel waste glass added to the mixture increased. The geopolymer containing $10 \%$ waste glass had a higher compressive strength than the others. For this geopolymer, as the $\mathrm{S} / \mathrm{N}$ increased from 0.75 to 1.75 , the compressive strength was 37.7, 46.6, 49.4, 58.2, and 63.3 MPa. The compressive strength increased with curing time, which supports the findings of other studies $[25,26]$, and indicates that polymerization continued toward the end of the curing period. Bernal et al. used slag and metakaolinite as the geopolymer, the amount of metakaolinite replaced the granulated blast fur-

Fig. (6). Flexural strength of geopolymer at various $\mathrm{S} / \mathrm{N}$.

nace slag (GBFS) increased, the compressive strength of which decreased with the replacement. When the curing time at 60 days, the sample of GBFS/ (GBFS+MK) equal to 0.8 with $\mathrm{SiO}_{2} / \mathrm{Na}_{2} \mathrm{O} 2.0$ which compressive strength achieve about $58 \mathrm{MPa}$ [27] presents experiment results that are similar to those of this study.

\subsection{Flexural Strength of Geopolymer Contained Solar Panel Waste Glass}

Fig. (6) shows the flexural strength of the geopolymer containing solar panel waste glass after 1,7 , and 28 days of 
curing. The flexural strength of the geopolymer clearly varied according to its compressive strength: the flexural strength of the geopolymer increased with $\mathrm{S} / \mathrm{N}$, and the sample with $\mathrm{S} / \mathrm{N}=1.75$ had the highest flexural strength. The flexural strength of the geopolymer containing $10 \%$ solar panel waste glass at $\mathrm{S} / \mathrm{N}$ ratios of $0.75,1.0,1.25,1.5$, and 1.75 on Day 28 of curing was 4.6, 6.4, 7.2, 8.5, and 8.9 MPa, respectively. Additionally, increasing the amount of solar panel waste glass reduced the flexural strength of the geopolymer, and the geopolymer containing $10 \%$ waste glass had the highest flexural strength. Curing time had less effect than the $\mathrm{S} / \mathrm{N}$ or the waste glass replacement percentage, but the flexural strength nevertheless increased with curing time.

\subsection{FTIR Patterns of Geopolymer Contained Solar Panel Waste Glass}

Fig. (7) presents the FTIR spectra of geopolymercontaining solar panel waste glass at various $\mathrm{S} / \mathrm{N}$ molar ratios. The absorption bands at $3400 \mathrm{~cm}^{-1}$ and $1650 \mathrm{~cm}^{-1}$ were
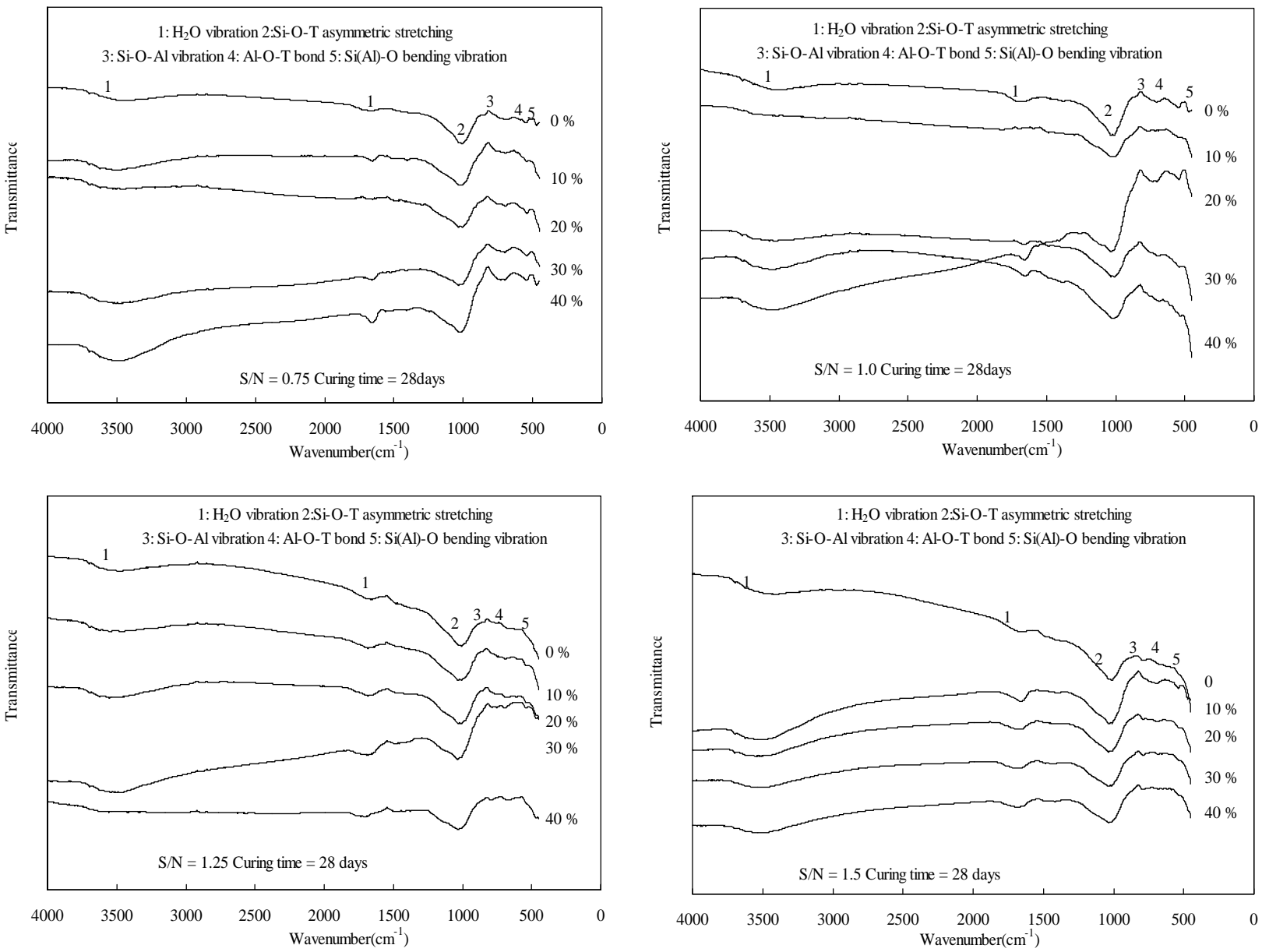

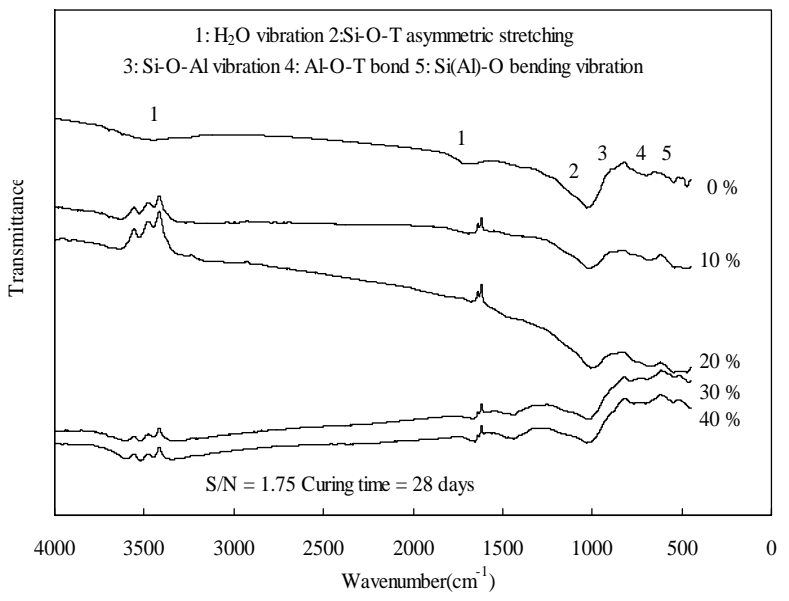

Fig. (7). FTIR patterns of geopolymer at various $S / \mathrm{N}$. 
associated with the adsorbed atmospheric water [28]. The strong peak at $1033 \mathrm{~cm}^{-1}$ corresponds to the asymmetric flexural vibration of the Si-O-Al and Si-O bonds [29]. A band at approximately $950 \mathrm{~cm}^{-1}$ was related to the asymmetric stretching vibrations of the Si-O-T (T: Si or Al in tetrahedral coordination) bonds in the geopolymer network [30]. The band at approximately $450-465 \mathrm{~cm}^{-1}$ was attributed to the in-plane Si-O bending [28].

The intensity of the peak from the geopolymercontaining solar panel waster glass at approximately 1033 $\mathrm{cm}^{-1}$, associated with Si-O-Al, increased with $\mathrm{S} / \mathrm{N}$, probably because more gel was formed at a higher $\mathrm{S} / \mathrm{N}$, producing larger silicate oligomers, which reacted with $\mathrm{Al}(\mathrm{OH})^{4-}$. However, the intensity of the main peak, associated with Si-O-Al, decreased slightly as the amount of waste glass increased, and the intensity of the band that corresponded to the adsorbed atmospheric water increased, revealing that the solar panel waste glass had a diluting effect.

\subsection{SEM Observation of Geopolymer Contained Solar Panel Waste Glass}

Fig. (8) shows the morphological characteristics of the geopolymer sample containing $10 \%$ waste glass with various $\mathrm{S} / \mathrm{N}$ molar ratios after 28 days of curing. The geopolymer samples with a higher $\mathrm{S} / \mathrm{N}$ had a denser structure, corresponding to a higher strength and bulk density, probably because the sodium silicate was more viscous than the sodium hydroxide, thereby filling the small pores of the geopolymer. Furthermore, a more compact and homogenous microstructure was associated with the increased formation of gel at a higher $\mathrm{S} / \mathrm{N}$ molar ratio. In contrast, a geopolymer sample with a lower $\mathrm{S} / \mathrm{N}$ molar ratio was less dense and had more noticeable pores, and therefore had a lower strength.

Fig. (9) presents the morphological structure of geopolymer containing $0 \%-40 \%$ waste glass at an $\mathrm{S} / \mathrm{N}$ of 1.75 after 28 days of curing. The amount of solar panel waste glass also affected the microstructure of the geopolymer: increasing the amount of solar panel waste glass made the structure more compact, and more unreacted raw material was observed. However, the geopolymer containing $10 \%$ waste glass had a dense structure, which was associated with its highest mechanical strength.

\section{CONCLUSION}

Based on these data, solar panel waste glass can be used as a source material for producing geopolymer, and the $\mathrm{S} / \mathrm{N}$ mole ratio of the geopolymer has a significant effect on its properties. The following conclusions are drawn from the experiments. The bulk density of geopolymer increased as $\mathrm{S} / \mathrm{N}$ increased, and decreased as more waste glass was added. The porosity of the geopolymer varied conversely. The compressive strength of geopolymer containing solar panel waste glass increased with $\mathrm{S} / \mathrm{N}$. The geopolymer mortar containing $10 \%$ waste glass at an $\mathrm{S} / \mathrm{N}$ of 1.75 had the highest compressive strength. FTIR results demonstrate that the intensity of the peak from the geopolymer-containing solar panel waste glass that was associated with $\mathrm{Si}-\mathrm{O}-\mathrm{Al}$ at approximately $1033 \mathrm{~cm}^{-1}$ increased with $\mathrm{S} / \mathrm{N}$. However, the intensity of the main peak decreased as the amount of waste glass increased. The $\mathrm{S} / \mathrm{N}$ ratio had a significant effect on the microstructure

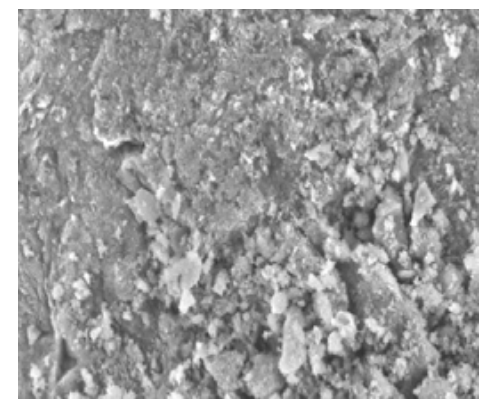

$\mathrm{S} / \mathrm{N}=0.75$

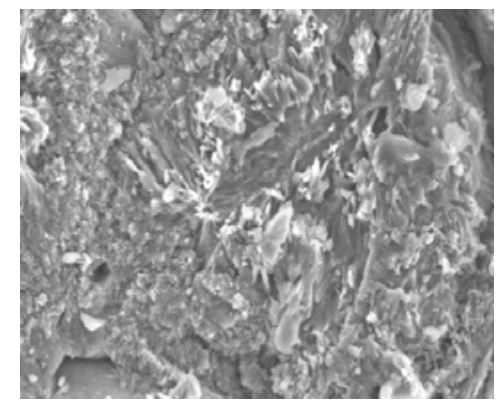

$\mathrm{S} / \mathrm{N}=1.0$

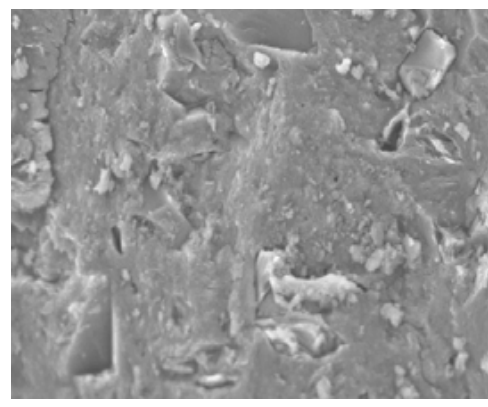

$\mathrm{S} / \mathrm{N}=1.25$

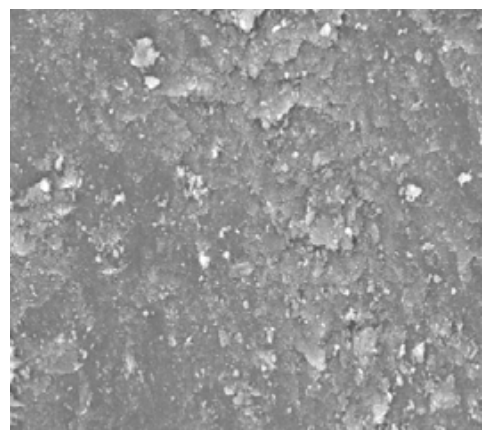

$\mathrm{S} / \mathrm{N}=1.5$

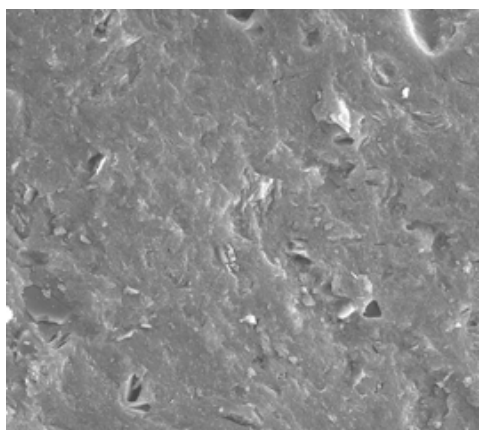

$\mathrm{S} / \mathrm{N}=1.75$

Fig. (8). SEM micrograph of geopolymer containing $10 \%$ waste glass at various $\mathrm{S} / \mathrm{N}$. 


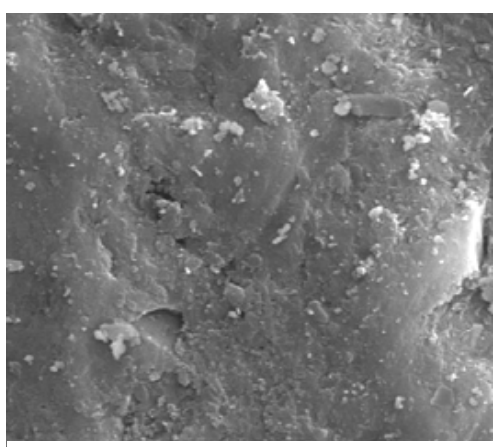

$0 \%$

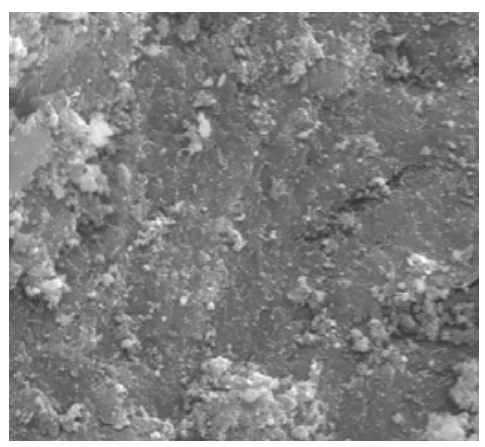

$10 \%$

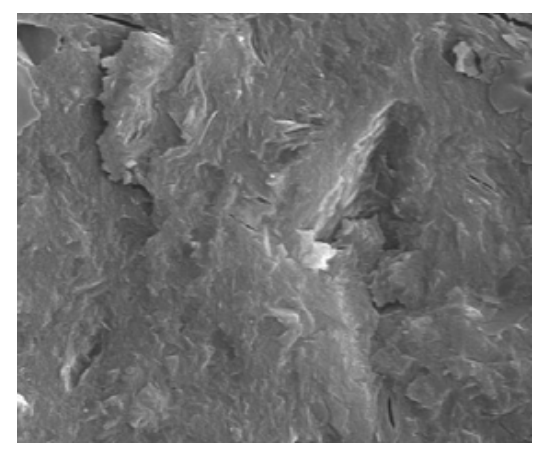

$20 \%$

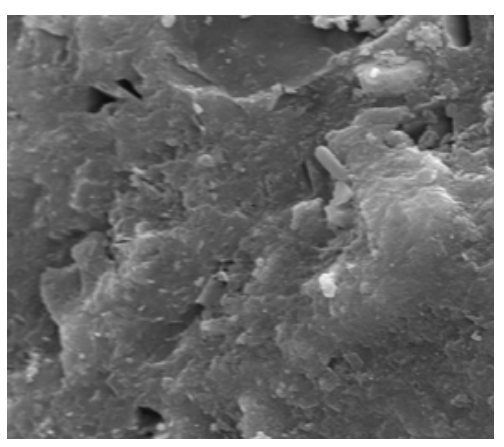

$30 \%$

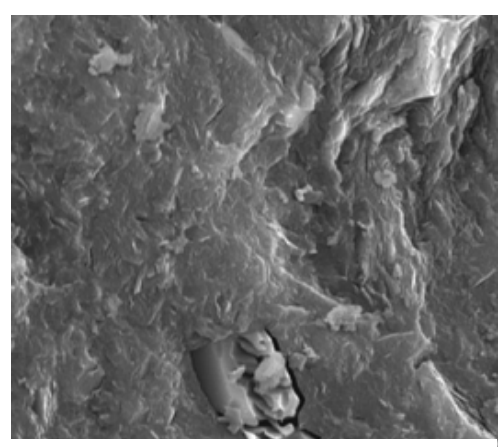

$40 \%$

Fig. (9). SEM micrograph of geopolymer containing various waste glass at $\mathrm{S} / \mathrm{N}$ of 1.75 .

of the geopolymer. Samples with higher $\mathrm{S} / \mathrm{N}$ appeared to have denser structures, corresponding to their higher strength and bulk density. The $\mathrm{S} / \mathrm{N}$ ratio also had a significant effect on geopolymer properties; the optimal value was $\mathrm{S} / \mathrm{N}=1.75$, and the optimal amount of solar panel waste glass was $10 \%$. A geopolymer with such properties has the most favorable high compressive strength.

\section{CONFLICT OF INTEREST}

The authors confirm that this article content has no conflicts of interest.

\section{ACKNOWLEDGEMENT}

The authors would like to thank for the Department of Industrial Technology (DoIT) of the Ministry of Economic Affairs of the Republic of China, Taiwan, for financially supporting this research under Contract No. 100-EC-17-A10-S1-151.

\section{REFERENCES}

[1] J. Davidovits, "Geopolymers: Inorganic polymerie new materials," J. Therm. Anal., vol. 37, pp. 1633-1656, 1991.

[2] D. Khale, and R. Chaudhary, "Mechanism of geopolymerization and factors influencing its development: a review," Mater. Sci., vol. 42, pp. 729-746, 2007.

[3] J.W. Phaira, J.S.J. Van Deventer, and J.D. Smith, "Effect of Al source and alkali activation on $\mathrm{Pb}$ and $\mathrm{Cu}$ immobilisation in fly-ash based "geopolymers," Appl. Geochem., vol. 19, pp. 423-434, 2004.
[4] D.R.M. Brew, and K.J.D. MacKenzie, "Geopolymer synthesis using silica fume and sodium aluminate," J. Mater. Sci., vol. 42, pp. 3990-3993, 2007.

[5] D. Panias, I.P. Giannopoulou, and T. Perraki, "Effect of synthesis parameters on the mechanical properties of fly ash-based geopolymers," Colloids Surf. A Physicochem. Eng. Asp., vol. 301, pp. 246254, 2007.

[6] P. Duxson, S.W. Mallicoat, G.C. Lukey, W.M. Kriven, and J.S.J. van Deventer, "The effect of alkali and $\mathrm{Si} / \mathrm{Al}$ ratio on the development of mechanical properties of metakaolin-based geopolymers," Colloids Surf. A Physicochem. Eng. Asp., vol. 292, pp. 8-20, 2007.

[7] A. Sathonsaowaphak, P. Chindaprasirt, and K. Pimraksa, "Workability and strength of lignite bottom ash geopolymer mortar," $J$. Hazard. Mater., vol. 168, pp. 44-50, 2009.

[8] A.S.D. Vargas, D.C.C. Dal Molin, A.C.F. Vilela, F.J.D. Silva, B. Pavão, and $\mathrm{H}$. Veit, "The effects of $\mathrm{Na}_{2} \mathrm{O} / \mathrm{SiO}_{2}$ molar ratio, curing temperature and age on compressive strength, morphology and microstructure of alkali-activated fly ash-based geopolymers," Cem. Concr. Compos., vol. 33, pp. 653-660, 2011.

[9] J.H. Chen, J.S. Huang, and Y.W. Chang, "Use of reservoir sludge as a partial replacement of metakaolin in the production of geopolymers," Cem. Concr. Compos., vol. 33, pp. 602-610, 2011.

[10] J. Deubener, G. Helsch, A. Moiseev, and H. Bornhöft, "Glasses for solar energy conversion systems," J. Eur. Ceram. Soc., vol. 29, pp. 1203-1210, 2009.

[11] N.C. McDonald, and J.M. Pearce, "Producer responsibility and recycling solar photovoltaic modules," Energy Policy, vol. 38, pp. 7041-7047, 2010.

[12] V.M. Fthenakis, "End-of-life management and recycling of PV modules," Energy Policy, vol. 28, pp. 1051-1058, 2000.

[13] K.L. Lin, "Use of thin film transistor liquid crystal display (TFTLCD) waste glass in the production of ceramic tiles," J. Hazard. Mater., vol. 148, pp. 91-97, 2007.

[14] R.R. Menezes, M.I. Brasileiro, L.N.L. Santana, G.A. Neves, H.L. Lira, and H.C. Ferreira, "Utilization of kaolin processing waste for the production of porous ceramic bodies," Waste Manage. Res., vol. 26, pp. 362-368, 2008. 
[15] U. Rattanasak, P. Chindaprasirt, "Influence of $\mathrm{NaOH}$ solution on the synthesis of fly ash geopolymer," Miner. Eng, vol. 22, pp. 1073-1078, 2009.

[16] ASTM C109 / C109M - 11b Standard Test Method for Compressive Strength of Hydraulic Cement Mortars (Using 2-in. or [50$\mathrm{mm}$ ] Cube Specimens)

[17] ASTM C348 - 08 Standard Test Method for Flexural Strength of Hydraulic-Cement Mortars Anonymous.. Test methods for evaluating solid waste. Taiwan EPA NIEA R208.04C 2009.

[18] T.W, Cheng, and J.P. Chiu, "Fire-resistant geopolymer produced by granulated blast furnace slag," Miner. Eng., vol. 16, pp. 205$210,2003$.

[19] A. Fernández-Jimenez, A.G. de la Torre, A. Palomo, G. L'opezOlmo, M.M. Alonso, and M.A.G. Aranda, "Quantitative determination of phases in the alkaline activation of fly ash. Part II: Degree of reaction," Fuel, vol. 85, pp. 1960- 1969, 2006.

[20] S. Delair, É. Prud'homme, C. Peyratout, A. Smith, P. Michaud, L. Eloy, E. Joussein, S. Rossignol, "Durability of inorganic foam in solution: The role of alkali elements in the geopolymer network," Corros. Sci. vol. 59, pp. 213-221, 2012.

[21] E. Prud'homme, P. Michaud, E. Joussein, C. Peyratout, A. Smith, S. Arrii-Clacens, J.M. Clacens, S. Rossignol, "Silica fume as porogent agent in geo-materials at low temperature," J. Eur. Ceram. Soc., vol. 30, pp. 1641-1648, 2010.

[22] M.D. Allendorf, K.E. Spear, "Thermodynamic analysis of silica refractory corrosion in glass-melting furnaces," J. Electrochem. Soc., vol. 148, pp. B59-B67, 2001.
[23] Z. Aly, E.R. Vance, D.S. Perera, J.V. Hanna, C.S. Griffith, J. Davis, D. Durce, "Aqueous leachability of metakaolin-based geopolymers with mole ratios of $\mathrm{Si} / \mathrm{Al}=1.5-4$, , J. Nucl. Mater., vol. 378, pp.172-179, 2008.

[24] R.R. Lloyd, J.L. Provis, J.S.J. van Deventer, "Acid resistance of inorganic polymer binders. 1. Corrosion rate," Mater. Struct., vol. 45, pp. 1-14, 2011.

[25] Y.J. Zhang, Y.C. Wang, and D.L. Xu, "Mechanical performance and hydration mechanism of geopolymer composite reinforced by resin,” Mater. Sci. Eng. A, vol.527, pp. 6574-6580, 2010.

[26] M. Criado, A. Fernández-Jiménez, and A. Palomo, "Alkali activation of fly ash. Part III: Effect of curing conditions on reaction and its graphical description," Fuel, vol. 89, pp. 3185-3192, 2010.

[27] S.A. Bernal, J.L. Provis, V. Rose, R.M. de Gutierrez, "Evolution of binder structure in sodium silicate-activated slag-metakaolin blends," Cem. Concr. Compos., vol. 33, pp. 46-54, 2011.

[28] K. Pimraksa, P. Chindaprasirt, A. Rungcheta, K. Sagoe-Crentsil, and T. Sato, "Lightweight geopolymer made of highly porous siliceous materials with various $\mathrm{Na}_{2} \mathrm{O} / \mathrm{Al}_{2} \mathrm{O}_{3}$ and $\mathrm{SiO}_{2} / \mathrm{Al}_{2} \mathrm{O}_{3}$ ratios," Mater. Sci. Eng. A, vol. 528, pp. 6616-6623, 2011.

[29] C.A. Rees, J.L. Provis, G.C. Lukey, and J.S.J. Van Deventer "The mechanism of geopolymer gel formation investigated through seeded nucleation," Colloid Surf. A, vol. 318, pp. 97-105, 2008.

[30] A. Hajimohammadi, J.L. Provis, and J.S.J. van Deventer, "Timeresolved and spatially-resolved infrared spectroscopic observation of seeded nucleation controlling geopolymer gel formation," $J$. Colloid Interface Sci. vol. 357, pp. 384-392, 2011. 